\title{
ARTICLE \\ Post-Brexit UK Fund Regulation: Equivalence, Divergence or Convergence?
}

\author{
Elizabeth Howell ${ }^{1}$ \\ Published online: 11 February 2020 \\ (c) The Author(s) 2020
}

\begin{abstract}
The UK's collective investment scheme ('CIS') sector is a key aspect of UK financial services. With the UK's departure from the EU, it has also become a politically salient topic, with various Member States competing to lure business to their financial centres in the light of Brexit. Brexit prompts hard choices and a key question arising for the CIS industry is whether the UK should continue to shadow EU law or whether elements of regulatory divergence could be envisaged. The paper suggests that, over the short to medium term, the UK should ensure it is likely to be deemed equivalent under EU law. Be that as it may, the paper also suggests that there may be areas within UK CIS regulation where some limited divergence can be considered. This would be provided that the UK remains in line with international standards, and (ideally) continues to be recognisably similar to remain equivalent. This certainly holds true in the event that equivalence is interpreted as more of a holistic assessment that could extend to embrace an element of regulatory competition. Any such divergence could also be framed as being of an optional nature, in order to grant CIS businesses full flexibility with respect to which regime they wish to comply. Writ large, Brexit may also help to stimulate broader conversations about the longer-term challenges the CIS industry faces in today's world. Viewed in this light, leaving the union could also inspire innovative and proportionate solutions to support and strengthen this pivotal sector.
\end{abstract}

Keywords Financial regulation · Fund regulation $\cdot$ Brexit $\cdot$ EU law

\section{Introduction}

The UK's collective investment scheme ('CIS') sector is a key aspect of UK financial services. With the UK's forthcoming departure from the EU, it has also become a politically salient topic, with various Member States competing to lure business to

Elizabeth Howell

E.Howell@1se.ac.uk

1 Assistant Professor of Law, London School of Economics and Political Science, London, UK 
their financial centres in the light of 'Brexit'. ${ }^{1}$ Brexit prompts hard choices and a key question arising for the CIS industry is whether the UK should continue to shadow EU law or whether elements of regulatory divergence could be envisaged. ${ }^{2}$ With a view to a greater understanding of the nuance contained within this issue, this paper considers the case study of the UK's CIS sector, which is of considerable significance to the UK's economy. ${ }^{3}$ Asset management firms invest and manage large sums of money for investors (ranging from individuals to institutions and governments); they invest in a broad range of UK and international enterprises, and make financial decisions that will affect their clients' financial wellbeing. Asset managers offer expertise, asset diversification, and economies of scale which investors would not be able to obtain investing individually, resulting in lower transaction costs. ${ }^{4}$ The City of London has long specialised in asset management, ${ }^{5}$ and an abundance of reports quantify its importance to the UK. The sector serves a global client base; it is the second largest in the world after the US; and it is the largest in Europe. ${ }^{6}$ It supports an estimated 100,000 jobs in the UK, and is a key driver of funding for the UK's economy. ${ }^{7}$

With respect to CIS regulation, there are a number of core issues and challenges facing the industry, which are by no means limited to those posed by Brexit. Financial regulation is a highly dynamic area and strong forces exist which can drive change with respect to its regulation, from the international to the local. For example, the importance of the CIS sector, and more generally of market-based finance (non-banking-based finance), has significantly increased since the global crisis when this acted as a substitute for bank lending. This is now to the extent that the sector's concentration has increasingly drawn the attention of global regulators with respect to potential financial stability concerns. ${ }^{8}$ At the EU level, the industry is an important funding driver behind the Commission's Capital Markets Union ('CMU') project (which seeks to create an internal capital market and immerse market-based finance in the EU, whilst reducing reliance on bank lending). ${ }^{9}$ At the domestic level, the CIS market is also on the UK's regulator's radar, including with respect to agency problems investors can face in relation to CIS managers. This has culminated in new provisions aiming to restore savers' trust in the industry, improving competition, as well as plans geared at improving the information being disclosed by

\footnotetext{
1 See e.g. Walker (2018a); Latham (2018).

2 Armstrong (2018), p 1099.

3 European Parliament (2016); The Investment Association (2017).

4 EFAMA (2017), Section 2.

5 Such businesses tend to concentrate in financial centres to facilitate access to world-class pools of talent and capital, as well as availability of financial infrastructures, Lannoo (2017).

${ }^{6}$ European Parliament (2016). For instance, in 2017, it managed $£ 7.7$ trillion of assets, with over £3 trillion managed on behalf of overseas clients, The Investment Association (2018a).

7 The Investment Association (2018a); Ernst and Young (2017).

8 See e.g. International Organisation of Securities Commissions (2018). Prudential regulators are also taking an interest, FSB (2017).

9 See European Commission (2015, 2017a).
} 
managers. ${ }^{10}$ Accordingly issues surrounding CIS regulation are not simply Brexitfacing, although Brexit offers a valuable case study as to how this topic can generate serious problems, but also produce new thinking. ${ }^{11}$

It is axiomatic that Brexit creates uncertainties and difficult choices for the industry. Most prominently, by the UK being an EU Member State, financial services firms authorised in the UK can easily provide services across the EU without the need for further local authorisations (often referred to as 'passporting'). ${ }^{12}$ Passporting is based on the assumption that EU-authorised firms will all have met the same standards and should be treated as if they were locally authorised. In the CIS sphere, such rights have enabled authorised CIS firms to easily market funds into and within other Member States, and the UK being part of the EU has granted it access to the world's largest single market. EU membership has also enabled UK firms to set up, manage and market CISs in a variety of forms, including on a cross border basis. ${ }^{13}$ It has shaped the way fund managers conduct their business; for instance, enabling firms to establish a management presence in the UK, domiciling their funds in another Member State (often Luxembourg), distributing the fund across the EU or internationally, and delegating the day-to-day investment management back to the $\mathrm{UK}^{14}$

On the working assumption that the UK will lose its passporting rights on leaving the EU, it will no longer benefit from the current access rights conferred via EU law. This is an issue of acute concern, especially given the cross-border nature of the CIS management sector and the vital importance of the passport to the industry. ${ }^{15}$ Rather, the UK will be classified as a 'third country' under EU law, and will be required to utilise the EU's 'equivalence' system in order to seek future access. In general terms, equivalence is a concept used by the EU to determine whether a third country's regulatory and supervisory regime is sufficiently similar to that of the EU's for access rights to be available. ${ }^{16}$ At the same time, there are clear disadvantages to relying on this set up. Only some EU financial services legislation provide for an equivalence regime (and as discussed further in Sect. 2 below, the CIS regime only has limited third country rules); the EU-decision process with respect to

\footnotetext{
10 FCA (2017, 2018a); 'FCA Reveals Strict New Rules for Asset Managers', Financial Times, 5 April 2018; FCA (2018b).

11 Note that individual (or discretionary) asset management as covered under MiFID II/MiFIR has developed separately under the EU regime and is excluded from this analysis, see Moloney (2017a).

12 House of Lords European Union Committee (2016), chapter 2.

13 E.g. at the end of 2016, 244 asset management firms out of the 1840 authorised in the UK had an outbound passport under the CIS regimes enabling them to do business in other Member States; and 139 firms had inbound passports enabling them to sell financial services into the UK, see ibid., pp 11-12; Europe Economics (2016).

14 PricewaterhouseCoopers (2018).

15 See Armour (2017) who states 'the potential loss of this ability to passport services throughout the EU is at the centre of the financial sector's concerns over Brexit'; see also House of Commons European Scrutiny Commitee (2018), Section 3.

16 Wei (2007). See also Sect. 2 below.
} 
granting access rights can be complex and slow; and such decisions can be unilaterally revoked by the Commission on relatively short notice. ${ }^{17}$

Accordingly, Brexit will introduce additional layers of legal complexity and costs for the UK CIS industry, and there are no guarantees with respect to future market access rights. At the same, however, markets and financial regulation are used to change; they constantly co-evolve. In this regard, Brexit need not necessarily be destructive for the UK, and there can be opportunities in terms of its CIS regulation. The broader context is also significant; in the arena of European financial services legislation, the UK has often played a valuable role in influencing the direction of travel of EU rules. ${ }^{18}$ During its membership of the EU, the UK has been known as a type of 'market making' economy, focused on ensuring the openness of London and the EU to international markets. It has often served as a counter-point to the more prescriptive, rule based and public authority orientated 'market-shaping' economies such as France and Germany, which can run the risk of veering into veiled protectionism. ${ }^{19}$ The UK's interests and drivers are significant and they will continue to shape how the UK makes choices with respect to regulatory design in the future. Connected to this, the UK also has important policy choices to make on whether and to what extent EU CISs and managers can continue to access the UK's markets either unilaterally or in exchange for UK access. ${ }^{20}$ A UK approach focused on openness to the EU's CIS system would be in its interest in maintaining London's reputation as a global financial centre. ${ }^{21}$

The paper suggests that, over the short to medium term, the UK should ensure it is likely to be deemed equivalent under EU law. This will enable existing access arrangements to continue as far as possible, and mean the UK's CIS sector can market and manage funds at least to some extent within the EU. Be that as it may, the paper also suggests that there may be areas within UK CIS regulation where some limited divergence can be considered. This would be provided that the UK remains in line with international standards, and (ideally) continues to be recognisably similar to remain equivalent. This certainly holds true in the event that equivalence is interpreted as more of a holistic assessment that could extend to embrace an element of regulatory competition. The paper draws specifically on the example of recent EU proposals within the CIS sector to demonstrate that, in the event that such initiatives severely impeded upon the operations of the UK fund sector, the UK could embark upon the path of limited divergence, and inject a targeted element of regulatory competition into the equation. Any such divergence could also be framed as being of an optional nature, in order to grant CIS businesses full flexibility with

\footnotetext{
17 Ringe (2017). Moreover subsequent changes to the EU's regulatory framework post-Brexit will also be of major consequence to the UK, given the size of the CIS market. In particular, the UK as a 'rule taker' will not be in a position to influence and shape the nature of any such changes at the negotiating table.

18 See e.g. Ferran (2004).

19 See Quaglia (2011).

20 AIMA (2018), p 5.

21 Ibid.; Armour (2017).
} 
respect to which regime they wish to comply. ${ }^{22}$ Writ large, Brexit may also help to stimulate broader conversations about the longer-term challenges the CIS industry faces in today's world. 'Fintech' technologies are likely to transform the industry and create significant new challenges for it. ${ }^{23}$ Viewed in this light, leaving the Union could also inspire innovative and proportionate solutions to support and strengthen this pivotal sector.

This paper's inquiry is a legal one, yet as this area exists at the confluence of law, politics, and international financial relations, the analysis is also informed by insights stemming from the EU financial governance scholarship, and the political economy literature on financial market governance. Section 2 examines the existing EU CIS framework, with particular reference to the regime in place for third country funds and fund managers. Section 3 considers the political economy context behind the EU fund manager framework, including the Brexit factor. Section 4 analyses three key pressure points for the UK; the EU's third country access regime; the likely scope for future delegation arrangements in order to facilitate EU market access; and the current CIS proposals on pre-marketing practices. Section 5 discusses the future for the UK's regulatory system and how the UK could approach its regulation of its domestic fund industry. Section 6 concludes.

\section{EU Collective Fund Regulation and Brexit}

\subsection{CIS Regulation: The End of Passporting}

There are two main strands of EU CIS regulation: first, the EU retail funds regime (the Undertakings for Collective Investment in Transferable Securities framework, also referred to as the 'UCITS'). ${ }^{24}$ Such funds are marketed predominately at consumers; they pool and invest investor funds in accordance with a defined investment policy. The second strand is the (broadly) non-retail EU alternative fund managers' directive (also referred to as the 'AIFMD'). ${ }^{25}$ This concerns funds (such as hedge funds) that use alternative strategies (including via leverage) to try and amplify returns for investors. ${ }^{26}$ The AIFMD particularly focuses on the regulation of managers of alternative investment schemes, rather than the alternative funds themselves (which, by in large, target professional investors). ${ }^{27}$

These EU regimes are now well established, the CIS industry has adapted to them (albeit rather unwillingly with the AIFMD), and the passporting rights connected

\footnotetext{
22 Ferran (2017), pp 62-63.

23 Ernst and Young (2017).

24 Directive 2009/65/EC on the Coordination of Laws, Regulations and Administrative Provisions Relating to Undertakings for Collective Investment in Transferable Securities (UCITS) [2009] OJ L 302/32.

25 Directive 2011/61/EU of the European Parliament and of the Council of 8 June 2011 on Alternative Investment Fund Managers and amending Directives 2003/41/EC and 2009/65/EC and Regulations (EC) No 1060/2009 and (EU) No. 1095/2010 [2011] OJ L 174/1.

26 European Parliament (2016).

27 Ibid. See also Moloney (2014), chapter III.
} 
to both regimes are crucial given the sector's cross-border nature. As observed in Sect. 1, passporting enables firms authorised in one Member State to do business in other Member States without the need for further authorisations. It is especially as a consequence of these rights that CIS managers authorised in one EU jurisdiction can conduct regulated activities throughout the EU, set up funds in different forms, and manage these within a number of structures. For instance, it has enabled funds to concentrate in popular fund centres such as Dublin or Luxembourg whilst having a management base in London. ${ }^{28}$ It has also permitted non-EU managers (particularly from the US and Switzerland) to establish their management presence in the UK from which they passport into other countries. On the working assumption that the UK will lose its passporting rights on leaving the EU, all these rights fall away. The UK will no longer benefit from the current authorisations conferred via EU law and it will be regarded as a third country under EU law.

\subsection{UK as a Third Country: Equivalence?}

As identified in the paper's introduction, equivalence is a concept used by the EU to manage third country access to its markets, as well as with respect to how EU participants interact with third country entities. ${ }^{29}$ Where applicable, it allows third country participants to offer services to EEA clients on the condition that the rules and supervisory framework of their home jurisdiction is deemed equivalent to those of the EU's. ${ }^{30}$ Yet, it is an inadequate substitute for the passport. There is no overall third-country framework; instead this is a spectrum of different regimes, ranging from no to extensive provisions. ${ }^{31}$ Moreover, the Commission is generally in charge of third country equivalence determinations. This generates the legitimate concern that decisions regarding the UK could risk becoming politicised (even when tempered by the role of the technocrat, the European Securities and Markets Authority ('ESMA') who often assists the Commission with making such assessments). ${ }^{32}$ Further, although in theory it should be straightforward to assess the UK as equivalent, given it has implemented all EU law as a Member State, it will fall to the Commission to assess whether the UK continues to remain sufficiently aligned with EU law going forward. ${ }^{33}$ In this regard, the Commission also has the discretion to withdraw

\footnotetext{
${ }^{28}$ Europe Economics (2017). Luxembourg was the first country to implement the UCITS Directive and attracted a number of promoters including Switzerland and the USA. The success of jurisdictions such as Luxembourg in attracting investment funds may be attributed to various factors, not least its reputation in the industry, a known regulatory environment, and favourable tax environment (fund domicile determines its tax treatment).

29 Moloney (2017a).

30 European Commission (2017b), p 7.

31 Lannoo (2017).

32 House of Lords European Union Committee (2016), p 23.

33 European Union (Withdrawal) Act 2018; House of Lords European Union Committee (2016). See also HM Treasury, AIFMD (EU Exit) Regulations (Draft) (2018); HM Treasury, CIS (EU Exit) Regulations (Draft) (2018) that seeks to ensure the EU regimes continue to operate in the event the UK leaves the EU without securing a transitional period.
} 
such decisions on fairly short notice. The Commission's discretion to both grant and revoke such decisions is as an understandable quid pro quo for the fact that a third country authority could suddenly change its regime on a whim, nonetheless the fact remains that this route is a shaky basis for building a future cross-border UK/EU relationship.

Applied specifically to the CIS regime, the starting point is that it only has limited third country rules. This is an area where market access is not governed by any existing equivalence regime. The two strands of EU CIS regulation are examined below, and by way of introduction, for the UCITS legislation, there is no third country framework in operation. For AIFMD, access is currently based on local requirements within each Member State where access is sought.

\subsection{The UCITS Regime: Access Options}

The UCITS regime provides access to the EU's single market for the UK retail CIS sector, and the UK industry values the UCITS label (it is a badge internationally renowned and trusted) and its style of regulation, including ensuring a high level of investor protection. ${ }^{34}$ As regards the UCITS market access options, such funds are required under EU law to be established in the EU and managed by an EU management company. ${ }^{35}$ As witnessed above, there is no third country framework provided. Accordingly, for the UK CIS sector to continue directly managing and marketing such funds following Brexit, UCITS funds and their managers would need to redomicile in an EU Member State (although any UCITS funds which are offered solely to UK investors may chose not to do so). ${ }^{36}$ The UCITS regime does offer scope for there to be some delegation of operational functions to third countries, which suggests that there could be some continued outsourcing to the UK, but this is subject to compliance with the relevant legal requirements. For instance, where the remit concerns investment management, cooperation between the supervisory authorities must be ensured. Moreover, the Commission and ESMA have recently specified that a cooperation agreement must be in place, ${ }^{37}$ and that the use of nonEU branches will need to be based on objective reasons linked to the services

\footnotetext{
34 See further Moloney (2014), chapter III; Association of the Luxembourg Fund Industry (2012).

35 Directive 2009/65/EC on the Coordination of Laws, Regulations and Administrative Provisions Relating to Undertakings for Collective Investment in Transferable Securities (UCITS) [2009] OJ L 302/32 (as Amended by Directive 2014/91), Arts. 1, 5, 6 .

36 Although not the specific focus of this paper, Brexit will also affect the management and marketing of other EU investment funds, including the relatively new European Venture Capital Funds (EuVECA), the European Social Entrepreneurship Fund (EuSEF), and the European Long Term Investment Funds (ELTIF), which can be marketed to retail investors subject to restrictions. Currently there are very low levels of these funds but Commission proposals envisage ESMA as the single supervisor for this regime, European Commission (2017c).

37 UCITS IV, Art. 13; European Commission (2018a).
} 
provided in the non-EU jurisdiction. ${ }^{38}$ In essence, there must be substance to the entity in the home Member State.

Taken together, if a UCITS remains in the UK following Brexit, it will not be permitted to be marketed as a UCITS on an EU-wide basis; and EU investor access to investment opportunities could be blocked. ${ }^{39}$ Rather, as a matter of EU law, such a CIS will automatically be treated as a third country alternative investment fund and so it will fall within the scope of AIFMD. ${ }^{40}$ These are issues of considerable importance; the UCITS are popular retail investment funds (estimates point to such funds accounting for around $75 \%$ of all collective investments by small investors in Europe). Further, the alternative for UK-based managers of such funds having to comply with the AIFMD third country framework to market UCITS within the EU is a steep price to pay. ${ }^{41}$

\subsection{The AIFMD Regime: Access Options}

As observed above, UCITS that do not re-domicile in another Member State and remain in the UK after Brexit will have to seek access through the AIFMD regime. As a matter of EU law, such funds will be treated as a third country AIF, coming within the scope of the AIFMD. Accordingly the AIFMD's third country market access rules become of the upmost importance on Brexit for both UK retail funds seeking market access to the EU, and for alternative investment funds. Once again, the AIFMD option is not straightforward; its third country access provisions are extremely cumbersome. ${ }^{42}$ There are currently two access routes to the EU under the AIFMD. The first is a national private placement regime for the marketing of a managed fund to professional investors within a Member State (but not crossborder). ${ }^{43}$ This does not require compliance with the full scope of the AIFMD but it does require appropriate cooperation arrangements to be in place between the authority where the marketing is to take place and that of the third country. ${ }^{44} \mathrm{Mem}$ ber States have the discretion as to whether to activate this regime, and the framework allows for the imposition of stricter rules (so called 'gold plating'). In practice some Member States have not implemented this option, and others, including Germany, impose very restrictive conditions. ${ }^{45}$ In addition, each Member State decides

\footnotetext{
38 Art. 13 of the UCITS Directive does not detail the general delegation requirements but ESMA is of the view that its interpretation and transposition should be consistent with the principles specified in the AIFMD level 2 rules, see ESMA (2017); Maijoor (2018). Note that (as discussed in Sect. 4 below) the Commission has also proposed reinforcing coordination via the European Supervisory Authorities in relation to delegation and outsourcing of activities, European Commission (2017c).

39 Moloney (2017a).

40 UCITS IV (as amended), Art. 6; Directive 2011/65/EU on Alternative Investment Fund Managers [2011] OJ L 174/1, Art. 6; European Commission (2018a); Moloney (2017a).

41 House of Lords European Union Committee (2016), p 18.

42 See further Ferran (2011).

43 AIFMD, Art. 42.

44 Ibid., Art. 42(1)(b).

45 Clifford Chance (2016); Ferran (2017); AIFMD, Arts. 36 and 42.
} 
whether it permits marketing of all alternative investment funds (whether EU or non-EU) to retail investors, with many Member States restricting or prohibiting such marketing. ${ }^{46}$

The second is a third country fund manager EU passporting route. This is subject to authorisation by a Member State, and compliance with a range of conditions (including full compliance with the AIFMD). This option is yet to be 'switched on' by the Commission, however (and this 'flicking of the switch' will then lead to a phasing out of the national private placement regime). ESMA has provided advice regarding the jurisdictions to which the passport should be extended, but in 2015 it also called for a slow-down in approach. ${ }^{47}$ In the latest round of assessments in 2016, only five out of 12 non-EU countries received unqualified advice (with the remaining seven jurisdictions, including the US and Hong Kong, receiving qualified advice) and a general sense of a 'sitting on the fence' theme. ${ }^{48}$ As already observed, although the UK should be able to be regarded as equivalent at the point of its departure, the state of play with respect to other jurisdictions' assessments demonstrate that the process could be slow. Further, it could be, whether for political or competitive reasons, or simply because the UK is last in line, that it is placed at the back of the queue. ${ }^{49}$ Moreover, it is also likely that sufficient maintenance of the status quo becomes a stipulation of this passport being made available to UK fund managers. ${ }^{50}$

Aside from these routes, the AIFMD framework does permit delegation of management activities to non-EU managers, provided certain conditions are met (including a cooperation agreement), ${ }^{51}$ but not to the extent it can no longer be considered the manager of the fund. ${ }^{52}$ Indeed, as explored further in Sect. 4 below, the spectre of Brexit has now heralded a change in tone as to the appropriateness of existing delegation arrangements, suggesting this avenue is not a panacea.

Taken together, Brexit introduces extra layers of legal and political complexity with respect to the UK's CIS sector, and the future compliance with EU law will generate considerable additional costs for the industry. UK UCITS will have to redomicile, or be required to follow the alternative fund industry in abiding by the AIFMD's third country access provisions. These requirements are a bitter pill to swallow for the industry to have future access to the EU's markets.

\footnotetext{
46 AIFMD, Art. 43.

47 Ibid., Arts. 35, 37-41; see also ESMA (2016).

48 AIMA (2016).

49 Indeed in this regard, the ESMA's reluctance to confer the passport on the US suggest that such issues could influence the timing and the willingness to extend the passport to the UK, Davis (2016).

50 Ibid.; Clifford Chance (2016). For further analysis, see also Ferran (2017).

51 AIFMD, Art. 20; Delegated Regulation 231/2013/EU OJ L 83/1 supplementing Directive 2011/61/ EU of the European Parliament and of the Council with Regard to Exemptions, General Operating Conditions, Depositaries, Leverage, Transparency and Supervision ('AIFMD Level 2 Regulation'), Arts. 75-82. See also ESMA (2017).

52 See further, AIFMD Level 2 Regulation, recital 93, Art. 82.
} 


\section{The Political Economy Context}

\subsection{Why the Complexity?}

That the current access routes to the EU for third countries are not straightforward can be first explained by the fact that, historically, third country access regimes have often been postponed to the end of lengthy negotiations, heightening the risk of reaching 'rubbish compromises'. ${ }^{53}$ Further, there can be deep-rooted political battles involved during the legislative process. In general terms, and as this section discusses, there can be clashes between more market-focused economies, such as the UK, that have traditionally tended to advocate policies focused on lighter-touch regulation and notions of openness (including for third country actor access); and more market-shaping continental economies, (which may include Germany and France) that may have a preference for more prescriptive and public-orientated regulation. ${ }^{54}$

The convoluted framework now in place for third countries in the AIFMD has been clearly documented in the political economy and cognate literature. It is pertinent to draw insights from this in order to comprehend the likely future access setup for the UK's CIS industry. It also helps shed light on analogous political tensions now emerging, including with respect to the delegation regime. Indeed, such battles raise the question as to whether or not the EU could be likely to embrace a more facilitative approach to access routes for the UK CIS industry. If an accommodating stance does not appear likely, then this connects to a question explored in Sect. 5 as to how the UK should approach the future regulation of its domestic CIS industry.

\subsection{The Push to Regulate Alternative CISs: The ‘Old'...}

The particular move to regulate alternative investment funds at the EU level emerged following the global financial crisis. When the AIFMD was under negotiation, the debate over the proposed AIFMD third country provisions, including the passport system for non-EU fund managers, was especially fractious. A more liberal approach to the EU's third country access rules was supported particularly by the UK, as well as the international hedge fund industry. Opposition stemmed particularly from France, a stance that may have been driven by veiled protectionism concerns. ${ }^{55}$ The gulf between notions of openness to the international hedge fund industry stemming from the UK on the one hand, and the more protectionist stance of continental countries on the other can be understood, first in part, by reference to what Quaglia terms the 'old' political economy of hedge fund regulation. ${ }^{56}$ This strand of literature suggests that institutionally shaped economic interests rooted in national varieties of capitalism can shape national preferences and can help explain

\footnotetext{
53 House of Lords European Union Select Committee (2015) per comments of Sharon Bowles; Ferran (2017).

54 Quaglia (2015); Ferran (2017).

55 Ferran (2017); 'France and UK Seek Hedge Fund Deal', Financial Times, 12 March 2010.

56 See the leading analysis of Hall and Soskice (2001).
} 
why some jurisdictions are keen to strictly regulate the alternative investment fund industry while others are not. ${ }^{57}$ Put simply this draws a distinction between two 'ideal-types' of political economies: liberal market economies (such as the UK); bank-based coordinated market economies (with Germany as the poster-boy example); and with France tending to fall in the middle. ${ }^{58}$ On this analysis, Member States will seek to have EU rules in line with their national regulatory approach and there will be national resistance to EU provisions that could distort the domestic model of capitalism. ${ }^{59}$ This can help to start explain the political economic causes of divergence between the EU and some Member States on EU proposals over the years, not least the famous example of takeover liberalisation, which was supported by the UK but which met with opposition from continental jurisdictions. ${ }^{60}$

\section{3 ....and the 'New'}

At the same time, there has also been an increasing blurring of these two ideals over the years, not least due to market developments, and a multitude of other factors including the impact of globalisation, international capital flow, and technology. Linked to this, Quaglia has developed a sophisticated variation, termed the 'new' political economy of regulation. This harnesses the initial concepts in Sect. 3.2, but also requires reference to the belief systems or 'policy paradigms' of coalitions within the EU and how these can shape national understandings and preferences. Specifically, this line of scholarship suggests that EU financial regulation policy is shaped by reference to two competing coalitions, the northern European group led by the UK, and the southern Europe group, which includes France, which prioritises financial stability and rule-based regulation. ${ }^{61}$ On this strand of analysis, Germany falls somewhere in the middle. ${ }^{62}$ Although ideas are inextricably intertwined with national political economy interests, the influence of the market-shaping paradigm can help explain the shifting balance of power towards market shaping coalitions in the light of the global crisis, including the EU push to regulate AIFMs. Specifically there could be the political use of ideas by market-shaping countries in order to promote their regulatory preferences. ${ }^{63}$

Nonetheless, it is necessary to remain cautious about generalisations. For example, in the AIFMD negotiations, there was often far more nuance to the UK's, and the other countries' responses; with different domestic preferences also

\footnotetext{
57 Quaglia (2011); see also Moloney (2016), Section 2.

58 As the terms suggest, market-based economies place an emphasis on competitive market arrangements, market based financing, a limited role for the state and a low degree of regulation. Bank-based economies place greater weight on long-term relationships with banks and other long term finance as well as regulated labour markets.

59 Buckley and Howarth (2010); Quaglia (2010, 2011).

60 Clift (2009); Callaghan and Höpner (2005).

61 Quaglia (2010, 2011).

62 Buckley and Howarth (2010).

63 'A New Pecking Order', The Economist, 7 May 2009, https://www.economist.com/node/13610767 (accessed 13 Apr 2018); Quaglia (2011).
} 
varying depending on the issue under the spotlight. For instance, although there was a Franco-German push to regulate the hedge fund industry, the scholarship acknowledges that this conceals the reality of domestic government policy. Indeed, the German government was instrumental in opening up the market to AIFs, and France had the largest concentration of AIFs in the EU aside from the UK. ${ }^{64}$ Accordingly, the Franco-German push to regulate was more linked to 'political legitimacy rather than principled disapproval of their activities' ${ }^{65}$ Moreover, as Ferran argues, the UK position also had more to it than was evident on first glance; the UK sought (unsuccessfully) to champion a global response to regulation of alternative investment fund managers. This was not least to avoid the risk of regulatory arbitrage, and to prevent the risk of EU markets being closed to third country fund managers and funds, particularly given the effects this could have on the international competitiveness of the markets. $^{66}$

Certainly, in the context of the debate over the third country access rules, France perceived the proposed third country regime as a means of ensuring financial stability and regulatory alignment of third country rules with those of the EU's. ${ }^{67} \mathrm{~A}$ French-led coalition, supported by many in the European Parliament (the 'Parliament'), pursued restrictive rules in order to 'prevent Europe becoming the Trojan horse' for alternative investment funds. ${ }^{68}$ Something tantamount to a small soap opera then unfolded with the US administration intervening via letters leaked to the press to the effect that these proposals required watering down, with hints that EU fund managers could otherwise face reprisals in Congress. ${ }^{69}$ The end result was the ultimate tempering of the most controversial proposals and with the Commission strategically reframing the rules as neither protectionist nor liberalising, all helping to explain the convoluted nature of the final set of third country rules. ${ }^{70}$

\subsection{Political Economy Battles and Brexit}

The preceding analysis provides valuable explanatory power with respect to the battles now playing out over CIS regulation in the light of Brexit. Specifically, France has publicly sought tighter regulation within the AIFMD; already imposes its own gold plating with respect to the third country regime and maintains that the existing equivalence framework requires reinforcing. ${ }^{71}$ Yet it also makes no secret of seeking to secure a larger slice of the EU fund management pie in Paris. ${ }^{72}$ In this regard,

\footnotetext{
64 Zimmermann (2009); Buckley and Howarth (2010).

65 Ferran (2012); Buckley and Howarth (2010); Zimmermann (2009).

66 Ferran (2012); Howarth and Quaglia (2017).

67 Quaglia (2015).

${ }^{68}$ Howarth and Quaglia (2014); Quaglia (2015).

69 Howarth and Quaglia (2014); Geithner (2010); Politi (2010).

70 Quaglia (2015); Ferran (2017).

71 In particular France states that it has 'long wanted stricter scrutiny of funds and more harmonisation of asset management rules across Europe', 'London's Asset Managers Fret over Prospect of EU Raids', Financial Times, 12 January 2018.

72 Howarth and Quaglia (2018); see also Latham (2018).
} 
political scientists reflecting on this canvas make a powerful argument (albeit caveated by the on-going developments surrounding Brexit). They suggest that there is now greater evidence of a 'neo-mercantilist' battle emerging amongst the Member States with respect to promoting their financial hubs and competing to attract business from the UK. ${ }^{73}$

For instance, although Germany has, in the main, been less vocal with respect to the issues emerging with respect to collective asset management and Brexit, the German regulator BaFin has also been pitching for business, and running workshops for asset managers considering migrating to Frankfurt. At the same time, Germany can be expected to play to its comparative advantage; what it can gain from Brexit will depend considerably on the 'old' national varieties of capitalism. ${ }^{74}$ In the context of collective asset management, given that Germany also competes with other countries that already have a firm foot in the door with management companies domiciled in Luxembourg, Dublin, or Paris, this may well add further nuance to its position. ${ }^{75}$ Domestic politics have also been dominating in Germany; and its new coalition has publicly opposed wider French moves towards greater levels of European integration. ${ }^{76}$ Of itself, this is in line with the important point that presupposing a commonality of interests between France and Germany can be erroneous. Many competing preferences and influences will affect the domestic response across and within a range of matters, and these can reasonably be expected to adjust in light of a shifting landscape, particularly that triggered by domestic elections, or an event such as a Member State's departure from the Union.

Accordingly, the political economy history provides meaningful guidance when applied to Brexit. It also reiterates that the UK industry may have an arduous and costly time ensuring access to individual Member States under the current regime. In this regard, this situation could also affect how the UK chooses to tackle the question of its domestic regulatory design over the longer term.

\section{UK: Key Pressure Points}

\subsection{UK Access to EU Markets: Third Country Status}

The broader political economy context surrounding the AIFMD demonstrates that the UK morphing into a third country generates considerable challenges with respect to its future market access rights. This section examines three particular pressure points materialising for the UK CIS industry. Moreover, although some of this analysis is necessarily speculative given live proposals on the table, informed insights on these sensitive areas can be usefully drawn from current understandings of the law, politics, and financial regulation.

\footnotetext{
73 Howarth and Quaglia (2018).

74 Ibid.

75 Dohle (2017); Ferran (2012).

76 See e.g. Münchau (2018).
} 
First, as identified above, if no UK/EU agreement with equivalent access is agreed, the UK's CIS industry will have to rely on the EU's third country mechanisms. This will require the UK to ensure it continues to shadow EU regulation in its law and supervisory arrangements sufficiently closely to be viewed as equivalent for EU law purposes. ${ }^{77}$ The preceding analysis has demonstrated the many legal and political weaknesses that this option has with respect to providing an access platform to the EU. ${ }^{78}$ The CIS third country provisions are rather "unwieldy ${ }^{\text {, }}$; ; the equivalence assessment process can be protracted; and the Commission can withdraw decisions unilaterally. ${ }^{80}$ Yet, from a pragmatic perspective, the most pressing short-to-medium term need is for the UK to be considered equivalent on day one of Brexit (which will either commence following the envisaged transition period, or earlier if there is 'no deal'). ${ }^{81}$ The UK being considered equivalent would avoid the risk of any sudden change of relationship between the UK and the EU (the risk of the so-called 'cliff edge').

Applied to the CIS sector, and starting with the AIFMD regime, as identified in Sect. 2, the general position is that UK CIS managers can, in principle, use the private placement framework for seeking access to particular markets. Further, if the Commission subsequently decides to give the green light on switching on the third country passport, the ESMA will also need to make an assessment as to whether the passport should be extended to the UK. The mirror image issue also presents itself with respect to what approach the UK should take to EU funds and fund managers seeking to continue to market EU funds to UK investors. This reflects a point true more widely: the UK has its own policy decisions to make on whether and to what extent EU entities can continue to have any preferential status, and whether this is unilaterally or in exchange for UK entities continuing to enjoy a reciprocal status in relation to EU activities. ${ }^{82}$

With this in mind, at present, a UK AIFM can relocate and become a full scope EU fund manager with the accompanying cost and compliance burden, or it will be subject to the private placement regime in a manner similar to other third countrybased fund managers. Access will be Member State dependent, and will require a cooperation agreement to be in place between the relevant supervisory authorities. ${ }^{83}$ As discussed in Sect. 2, existing Member State regimes differ very significantly across EU jurisdictions (Germany and France are highly restrictive; the UK, Ireland

\footnotetext{
77 European Commission (2017b).

78 See further, Moloney (2018a, b).

79 Moloney (2017b), p 124.

${ }^{80}$ For example the equivalence decision in relation to US clearing houses took over 3 years, see European Commission, Implementing Decision of 15 March 2016 on the Equivalence of the Regulatory Framework of the United States of America for Central Counterparties That Are Authorised and Supervised by the Commodity Futures Trading Commission to the Requirements of the EMIR Regulation (2016); Ferran (2017).

81 See e.g. Blitz (2018).

82 AIMA (2018).

83 AIFMD, Art. 42, also Arts. 22-24. The fund manager will also be subject to the Directive's disclosure and reporting regime.
} 
and Netherlands are more facilitative). Hence, how accommodating Member States are likely to be to UK managers, and the method and cost of compliance could vary dramatically. In particular, sustained access to the whole of the EU market using this basis alone appears very unlikely.

There is also the related timing issue that complicates this option. The AIFMD national private placement regime does not currently enable an entity that is not, at that time, a non-EU CIS manager to file the necessary paperwork. Further, in relation to current third country CIS managers, the administrative process has been estimated to take between 20 and 60 days. ${ }^{84}$ It may be that the juggling act of withdrawing existing registrations and filing the relevant documentation can be arranged during the transition period (in the event this occurs); but this will be Member State dependent. Further, and as witnessed in the political economy scholarship in Sect. 4, there are certainly risks as to more onerous conditions being imposed on a non-EU CIS manager at a Member State's discretion. With respect to the cooperation agreements, these are at the heart of many of the third country provisions in AIFMD (as well as more generally in current EU financial legislation). Accordingly the UK could, and most likely should, seek to sign cooperation agreements with each existing EU (and EEA) country. In this regard, adopting the current practice of using the agreed terms of ESMA's model memorandum of understanding governing the supervisory coordination arrangements between the relevant authorities would appear prudent. ${ }^{85}$

It may be that the commercial quid pro quo of EU fund managers wishing to continue to access UK investors can help to prevent any barriers swiftly emerging (indeed the ESMA, EU regulators and the UK's Financial Conduct Authority have now agreed multilateral memoranda of understandings to cover cooperation and exchange of information in the event the UK leaves without a deal) ${ }^{86}$ In this regard, the UK continuing to adopt a permissive stance with respect to market access would seem sensible. ${ }^{87}$ This could help limit the risk of possible disruption, and also send a positive signal in relation to setting up reciprocal flexible arrangements. Moreover, such reciprocity of treatment is likely to be a necessary condition for ESMA to make a positive assessment of the UK with respect to the conferral of the third country passport. On this point, the UK should seek to have ESMA perform its assessment during the transition period, although the reality of this materialising may be unlikely given ESMA's existing go slow policy. ${ }^{88}$ In addition, in line with Sect. 2, whether or not for political reasons, it could be in the Commission's interests to send the UK to the back of the queue. ${ }^{89}$ Further, recent Commission proposals advocated

\footnotetext{
84 AIMA (2018), p 7.

85 ESMA (2013); AIMA (2018).

86 FCA (2019).

87 See in this regard e.g. HM Treasury, AIFMD (EU Exit) Regulations (Draft); HM Treasury, CIS (EU Exit) Regulations (Draft), which take such a facilitative approach if the UK departs without a deal, broadly enabling EEA AIFMs and CISs to continue to market funds into the UK on the same terms as before.

88 See ESMA (2016); AIMA (2016).

89 Davis (2016).
} 
conferring greater power on ESMA and the other European Supervisory Authorities (the 'ESAs') to monitor equivalence decisions to ensure that the conditions for granting such a decision continue to be fulfilled. ${ }^{90}$ This suggests (and is further elucidated on below) that the UK continuing to shadow EU law sufficiently closely may become a condition of any UK equivalence decision. ${ }^{91}$

In relation to the UCITS framework, the practical implications are more straightforward; either a UK UCITS and CIS management company re-domicile to a Member State (in order to retain the UCITS badge), or the entities will be regarded as an AIF as a matter of EU law and will have to comply with the AIFMD (as discussed in Sect. 2.3 above). With respect to a UK UCITS only offering its shares or units to UK investors, such entities may choose to remain solely in the UK and the UK regulator would then need to determine whether such entities will be a UK UCITS, an alternative investment fund, or some other yet-to-be-defined entity. Equally, there is the same mirror image issue as to whether EU UCITS would be permitted to market these funds to UK investors. Again, the UK adopting a similarly tolerant approach based on adequacy of the EU's UCITS provisions would offer businesses commercial certainty, and could also help bolster the strength of the UK's case in eventually seeking to receive the AIFMD third country passport. ${ }^{92}$

\subsection{Delegation}

The fact remains that the EU's third country access route is not a silver bullet for the UK CIS industry. A further major pressure point emerging for the industry concerns the existing CIS delegation arrangements. As observed in Sect. 2, an alternative to navigating the third country maze-like structure involves a UK fund manager setting up a fund in a suitable Member State, most likely Luxembourg or Ireland, and delegating various management functions back to the UK. This enables alternative investment fund managers as well as UCITS management firms to delegate functions to a UK manager, and many UK fund managers already operate on this basis. ${ }^{93}$ Delegation is not derived from the EU passporting rights; rather this is an international convention that is used fairly frequently in practice (for example, it could be used with respect to a CIS domiciled in an EU Member State that focuses on Asian shares in order to benefit from the local insights drawn from Tokyo-based managers). ${ }^{94}$ The existing model has enabled centres such as Luxembourg and Dublin to emerge as the domicile of choice for the CIS sector, but with delegation arrangements occurring in other financial centres both within the EU (including the UK), but also further afield.

\footnotetext{
90 European Commission (2017c).

91 Moloney (2017c).

92 AIMA (2018).

93 Ashurt (2016). Although beyond the scope of the paper, this could also be true for individual asset management under MiFID II/MiFIR.

94 The Investment Association (2018b), p 9; House of Lords European Union Committee (2018), p 90.
} 
Nevertheless, Brexit has led to a change of tone on the appropriateness of the delegation arrangements. Although immersed within wider Commission initiatives, provisions have been proposed (that have since been contested) to place ESMA in the driving seat to oversee the CIS delegation arrangements. Specifically, the Commission's 2017 Proposal to Reform the European System of Financial Supervision ('ESFS') includes a new set of proposed competences with respect to the authorisation and supervision of non-EU actors. As identified in Sect. 4.1, it envisages a greater role for ESMA in equivalence decisions. It also places ESMA in a key position to oversee the CIS delegation mechanisms where this involves delegation to a third country, and to ensure coordination of supervisory action (including that a national authority notify ESMA in advance of authorising or registering a financial institution where there will be a delegation of a material part of its activities to a third country). ${ }^{95}$ Indeed, this particular power in relation to the oversight of CIS delegation arrangements directly builds on an earlier ESMA Opinion with respect to the relocation activities following the UK's withdrawal from the EU. ${ }^{96}$

The 2017 Proposal seeks to address concerns emerging as to varying supervisory practices throughout the EU leading to a race to the bottom. It also tackles financial stability risks where third country supervisory authorities lack the necessary tools to adequately and effectively supervise key functions. ${ }^{97}$ Nonetheless it is not difficult to discern a Brexit angle to it. At its core is an unwillingness to tolerate regulatory and supervisory arbitrage, and the inter-linked concern that EU firms not be token 'letterbox' entities that merely route business back to the UK. It is certainly reasonable to seek substance to entities in a Member State. Yet this should not come at the price of sacrificing current industry models that reflect the industry's global nature, and which has evolved around investors' best interests. ${ }^{98}$ This is linked to the broader point identified at this section's outset: delegation is not directly linked to the EU passport. Rather, this fairly standard practice is rooted in a well-established international norm and underpinned by strong standards and regulatory cooperation: an international convention to offer investment expertise.

As predicted by the analysis in Sect. 3, the ESFS Proposals have been divisive. Honing in on the specifics, France supported the introduction of stricter rules on third country outsourcing, whereas Luxembourg and Ireland have advocated retaining the current framework to preserve their own industries, and to avoid penalising third-country centres such as the US and Japan. In fact the US once again, stepped into oppose the changes. ${ }^{99}$ ESMA has since watered down some of its earlier

\footnotetext{
95 ESMA (2017); European Commission (2017c), recital 18; Art. 31a.

96 ESMA (2017).

97 European Commission (2017c), recital 18.

98 KPMG (2017).

99 Walker (2018b). See further, House of Lords European Union Committee (2018); Binham (2018). Other marketing-making countries including Sweden have also voiced concern as to the impact of the wider Commission proposals regarding ESMA on the overall competitiveness of the EU's financial markets, see 'European Finance Ministers Clash over Greater ESMA Powers', Luxembourg Times, 8 November 2017, https://luxtimes.lu/archives/498-european-finance-ministers-clash-over-greater-esma-powers (accessed 16 Apr 2018).
} 
rhetoric, and suggestions were also mooted that the advance notification requirements on delegation could be scrapped. ${ }^{100}$ At the time of writing, the 2019 Council Compromise Proposal retains the advance notification requirement, however it eliminates the strong discourse in the recital to the Commission Proposal with respect to the risks being particularly 'acute' in relation to supervised entities delegating activities to third countries. ${ }^{101}$ Taken together, the delegation option may assist UK asset management firms to an extent, but may not be the most solid foundation on which to build with respect to guaranteeing future market access to the EU. ${ }^{102}$

\subsection{Pre-marketing: The 2018 Fund Proposal}

The third major pressure point for the industry concerns the CIS pre-marketing framework. This is particularly relevant under the AIFMD, where managers are currently required to notify the local regulator, but only before marketing funds to EEA investors, including on a cross-border basis. Accordingly, pre-marketing can occur in the zone prior to this. Pre-marketing involves CIS managers approaching sophisticated investors in order to test investor appetite for upcoming investment strategies and to discuss key terms. This can be an extremely valuable market practice for fund managers; many alternative investment funds offer only periodic opportunities to invest (in contrast to UCITS, which tend to be offered on a continuous basis). Hence fund managers can use pre-marketing to identify interest and to define and refine important terms. ${ }^{103}$

Pre-marketing is governed by the AIFMD but only to the extent that the Directive includes a wide definition of marketing. Marketing is defined as 'any direct or indirect offering or placement at the initiative or on behalf of the AIFM, of units or shares in a fund it manages to or with investors domiciled in the EU'. ${ }^{104}$ This definition does not include reverse solicitation (where an investor approaches a fund on their own initiative and without any marketing). ${ }^{105}$ Other than this, no further guidance is provided, meaning the actual concept has been left open to interpretation. In line with the political economy analysis, practices have again diverged between Member States as to precisely what level of pre-marketing and other promotional activities are permitted before a marketing notification is required to be made to the regulator. ${ }^{106}$ In particular, consistent with earlier observations, the UK regulator

\footnotetext{
100 Investment and Pensions Europe (2018); Walker (2018c).

101 ECOFIN (2019a), eliminating recital 18. More generally, the Compromise Proposal also tempers some of the Commission's grand designs with respect to the ESFS reforms. Political agreement between the Council and Parliament on the Proposals was reached in March 2019.

102 Moloney (2018a), p 179.

103 European Commission (2018b). Note that, as observed in Sect. 2, any marketing of such funds to retail investors is subject to Member State control, and can be subject to additional regulation at the national level, see AIFMD, recital 71, Art. 43.

104 AIFMD, Art. 4(1)(x).

105 Ibid., recital 70 provides that AIFMD should not affect the current situation whereby a professional investor may invest in AIFs on its own initiative.

106 Ibid., Art. 4, Arts. 3, 32, and 42.
} 
currently takes a pragmatic view. It is only when the final documentation is provided that marketing occurs in the UK, and this liberal interpretation allows managers the flexibility to gauge interest, before being required to establish the fund, finalise the paperwork and notify the regulator. ${ }^{107}$

This is also now a topic of change, with knock-on implications for the UK. The Commission's 2018 Fund Proposal introduces a harmonised definition of pre-marketing to specify the conditions as to when an alternative fund manager can engage in such activities. ${ }^{108}$ Although it may be sensible to tackle divergent approaches that can result in barriers to cross-border marketing, the devil is in its detail. The Commission definition narrows the concept of pre-marketing, and the conditions under which any pre-marketing is permitted are very restrictive. It provides that pre-marketing should concern an investment idea or strategy without an actual fund having yet been established, and no draft offering or similar documents is permitted to be circulated to potential professional investors. On such a basis, this would mean that all documentation would effectively be required to be approved by a regulator very early in the process in order for a manager to be granted the marketing passport. This is even though such paperwork will likely be subject to further waves of negotiation that will then require further approval. ${ }^{109}$ Moreover, pre-marketing cannot be used to generate an 'own approach' from an investor in order to avoid the rules. Aside from this, however, the reverse solicitation scenario where the investor approaches a fund without any such (pre) marketing should not be affected. ${ }^{110}$ Yet, given that the Fund Proposal regards investments in relation to other similar not-yet-established funds of that manager as marketing, this will restrict reverse solicitation in practice. ${ }^{111}$ Finally, in terms of scope, the proposed conditions only apply to fully authorised EU managers. This suggests that the extent to which non-EU managers can engage in such pre-marketing will remain subject to the relevant national regime. ${ }^{112}$

The approach taken by the Commission is geared more towards the restrictive and less pragmatic of the existing national approaches. ${ }^{113}$ Ultimately, however, the end result has been pared back. ${ }^{114}$ The Council's 2019 Compromise Proposal adopts a more pragmatic tone with an approach more in keeping with existing CIS industry practice. It permits pre-marketing, including in relation to an established fund where a manager has not yet notified the regulator with respect to marketing (provided particular conditions are met), as well as enabling draft documentation to be circulated

\footnotetext{
107 FCA, AIFMD Marketing, PERG 8.37.6 (Perimeter Guidance Handbook 2013); Ashurt (2018).

108 European Commission (2018c), Arts. 2 and 30a. Note the proposals also include other provisions including requirements aimed at harmonising UCITS and AIFMD marketing communications, European Commission (2018d).

109 Schnittker Möllman Partners (2018).

110 European Commission (2018c), recital 11.

111 Debevoise and Plimpton (2018).

112 European Commission (2018c), Art. 30a.

113 Ibid.; Cleary (2018).

114 In particular, the UK working with other Member States have sought to secure changes, and negotiations have progressed 'unusually swiftly', see Glen (2018).
} 
to prospective investors. ${ }^{115}$ Nonetheless, strictly speaking the provisions only cover EU managers, meaning it remains open to Member States to apply a more restrictive definition to non-EU managers. ${ }^{116}$

When the various pressure points are viewed together, the implications for the UK seem fairly bleak. As outlined above, the EU's third country/equivalence rules are a wobbly basis for future access, and will result in extra compliance costs for the UK's CIS system. ${ }^{117}$ Further, in connection with the observations in Sect. 3, the efforts of the EU's leading financial centres to attract UK CIS businesses considering relocation have been well documented. ${ }^{118}$ Moreover, in light of the 2017 Proposals, the scope for the UK industry to rely on delegation as an access solution is less secure, and could be vulnerable to challenge by local regulators and ESMA. ${ }^{119}$ Finally, although the 2018 Proposal has now been mellowed to an extent, the position for a third country manager will remain at the discretion of the relevant Member State regime. Accordingly, disruption and additional costs for the industry can be anticipated.

\section{The UK's Future Regulatory Design}

\subsection{Equivalence, Divergence, or Convergence?}

Section 4 illustrated a number of problematic issues for the UK's CIS arena with respect to future EU access. Common to all these challenges is the posture of the UK on how it should tackle the subsequent regulation of its domestic CIS industry. Specifically, should the UK's own regulatory design involve continued convergence with EU law in a post-Brexit world, or might any regulatory divergence be expected. Of itself, this connects to a deeper issue; as Armstrong argues, the UK/EU relationship is not static, and financial regulation is highly dynamic. Accordingly there may be selected spaces where the UK can look to escape a direct battle with the EU (which it could be unlikely to win) and to develop a credible alternative response in order to be internationally competitive. ${ }^{120}$

As witnessed above, the UK has an extremely well established financial sector; its capability in the field of financial services predates its membership of the EU, and its

\footnotetext{
115 ECOFIN (2019b) recital 11, Art. 2 (revised). The Parliament's draft Report also sought to simplify the Commission conditions for pre-marketing and advocated introducing a more practical system; European Parliament (2018a, b). At the time of writing the legislation entered into force in August 2019, with Member States to apply implementing measures from 2 August 2021, see Directive 2019/1160 (EU) amending Directives 2009/65 and 2011/61 with regard to cross-border distribution of collective investment undertakings [2019] OJ L 188/106 ('AIFMD 2'), Art. 4(1) and Art. 30a.

116 See AIFMD 2, recital 12.

117 Moloney (2018a), p 179.

118 See e.g. Davies and MacAskill (2017); 'Britain Braced for Brexit Raid on £8tn Asset Management Industry', Financial Times, 3 January 2018; see also Moloney (2018b).

119 Moloney (2017a).

120 Armstrong (2018).
} 
CIS system serves a highly international client basis. ${ }^{121}$ The UK regulators also have renowned expertise in the field of financial regulation. Its markets regulator sought to influence the EU AIFMD when it was under negotiation, ${ }^{122}$ and at the national level it has been recently reviewing the CIS management industry, signalling the importance of UK regulation with respect to this crucial sector. ${ }^{123}$ In essence, the UK is a key international financial centre and one that is unlikely to lose its prominent position easily. As Moloney argues, there are 'very strong network effects' that attract capital to such centres, which have tried and tested infrastructures. ${ }^{124}$

With this in mind, when considering the future direction of travel for the UK's CIS sector, the UK is in a strong position to consider a domestic CIS policy that includes elements of regulatory divergence. As this section will discuss, this could put its equivalence determinations at risk. Yet, at the same time, there are ways around this (not least if the notion of equivalence becomes more pliable). Further, the benefits of (focused) divergence for the UK could be great.

Unpacking the nuance, especially if the outcome of the various CIS proposals severely impedes the functioning of the UK's CIS industry, it becomes conceivable that UK law could begin to diverge from EU law. In particular, the UK could engage in some targeted divergence from aspects of the AIFMD. Any such decisions could be clearly rationalised by drawing on the UK's deep-rooted market-oriented interests. Indeed these manifest themselves in the UK's existing CIS set-up, especially the UK's more permissive pre-marketing practices, as well as its stance towards third country entities seeking access via the UK's private placement regime. The proposition that there could be selected divergence also becomes more probable given that UK CIS managers are likely to be in a difficult position following their shift in status to third country actors. Accordingly, a UK domestic strategy framed around carefully considered regulatory divergence (including with respect to the parameters of permitted pre-marketing, and the related access arrangements) could reap important benefits for the UK. Writ large, such a stance could also involve the UK utilising its world-leading expertise in the field of fintech and applying this directly within the CIS industry over the longer term. Specifically, the UK is at the forefront of the fintech industry, including introducing the 'regulatory sandbox' to support innovation and test new products in a highly supervised environment. ${ }^{125}$ As fintech techniques have the ability to transform fund management over the longer term, the UK adopting a pioneering and measured approach with respect to its domestic CIS regulation could ensure it is globally competitive in a post-Brexit world.

As noted, there are risks. The prospect of regulatory divergence could jeopardise the UK's (still to be granted) equivalent status as far as EU law is concerned. But

\footnotetext{
121 International Monetary Fund (2016), Appendix II.

122 See e.g. FSA (2009), Section 4, question 19; House of Lords European Union Committee (2018), para. 44.

123 FCA (2017).

124 Moloney (2017c), chapter 7.

125 See e.g. House of Lords European Union Committee (2018); Ernst and Young (2017). Although in the context of individual investment advice and the limitations of the EU MiFID regime, see e.g. Ringe and Ruof (2018).
} 
this is not necessarily a fatal defect. First, ESMA has already deemed Jersey and Guernsey largely equivalent for the purposes of obtaining the third country passport under the AIFMD regime. As Ferran argues, these jurisdictions already offer a valuable element of optionality into their regulatory structures to ensure maximum flexibility for businesses; Jersey funds and managers can choose to be outside AIFMD, they can comply to the extent necessary to satisfy the national private placement regime, or they can opt to be fully EU compliant in anticipation of the EU third country passport. ${ }^{126}$ This signals that an element of regulatory optionality could be permissible in relation to the question of the UK being granted a favourable equivalence decision. ${ }^{127}$ Moreover, a regime based on optionality could be particularly attractive to UK alternative investment fund managers given that many of them currently already manage non-EU funds. ${ }^{128}$

Second, it may be that the idea of equivalence becomes more accommodating. This feeds into the actual concept: equivalence is a term that can be subject to varying interpretation (and which can itself end up being a bargaining chip in negotiations). Arguably the preferable view regards equivalence conceptually as more of a holistic assessment, often benchmarked against international standards, and which focuses on a high level of comparability, rather than a form of granular line-by-line examination. ${ }^{129}$ If equivalence does focus more on sufficiently similar systems and outcomes rather than identical forms, then this can also be seen to have some functional similarities to regulatory competition. It can allow some flexibility to be built into encourage global competitiveness, but without a jurisdiction being granted free reign. ${ }^{130}$ The Commission has certainly in the past supported the idea that equivalence could incorporate aspects of regulatory competition, including that the regulatory solution in one jurisdiction may not always work in another, and that there could be a 'managed competition' of equivalent systems based on common underpinnings. ${ }^{131}$ It has also acknowledged that promoting the competitiveness of the EU is a positive effect of an equivalence determination. ${ }^{132}$ This more malleable notion was also reflected, for instance, in the UK's 2018 White Paper, which respects the regulatory autonomy of the UK and EU, embraces an expanded 'enhanced equivalence' framework with an emphasis on outcomes rather than rulebooks, and articulates a commitment to upholding global norms. ${ }^{133}$

This suggests that, in principle, some managed regulatory competition by the UK could be viable. This would be on the proviso that the UK remains within the bounds of international standards, including (for the alternative fund sector) the

\footnotetext{
126 Carey (2017); Ferran (2017).

127 Ferran (2017).

128 Reynolds (2016).

129 Lehmann and Zetzsche (2018); Ferran and Ho (2014), chapter 14.

130 Wei (2007).

131 Schaub (2004); Wei (2007).

132 See European Commission (2017b), where the Commission recognises that there are positive effects in allowing EU market participants having access to a wider range of services and transaction choices; Reynolds (2017). See also the (defunct) European Council (2016), section B (competitiveness).

133 See HM Government (2018), section 1.3.4.
} 
International Organisation of Securities Commissions' ('IOSCO's') high-level principles on hedge fund regulation. In this regard, and as analysed above, existing UK practice with respect to asset management is currently recognised internationally, and it already accords with international norms. ${ }^{134}$ Hence, viewed in such a light, such a strategy should not come into conflict with an equivalence determination. ${ }^{135}$

Brexit-related regulatory change should also not be so unexpected given that waves of regulation and de-regulation tend to follow a familiar pattern; regulatory oversight increases after a crisis or scandal, and then wanes as society and the market returns to normal (the regulatory 'sine curve'). ${ }^{136}$ In the years that followed the global financial crisis, regulation and oversight over financial sector actors and products increased manifold around the developed world, not least in the EU, which applied a prescriptive, 'more Europe' approach to its post-crisis rulebook. ${ }^{137}$ More recently, however, and in line with the regulatory sine curve, deregulation is becoming more of a feature, not least when one observes US policy under the Trump administration, but also within the EU itself with its current CMU initiative. A deregulatory direction of travel by the UK would continue to follow the sine curve. ${ }^{138}$ The UK's interests in pursuing a market-making agenda also suggest that it should continue to present itself as a light-touch regulation jurisdiction.

At the same time, in practice, it is unlikely that there will be any large-scale deregulation occurring at the UK level. First, such a strategy would generate considerable transaction costs for a legacy industry such as the UK's CIS system. Next, UK regulators have traditionally chosen not to take a minimalist stance to regulatory design, and in fact often bolster the UK's laws via the gold plating of EU requirements. ${ }^{139}$ Further, since the global financial crisis, financial governance has been shaped around notions of regulatory convergence, rather than competition or regulatory arbitrage. Hence, although there have been some calls arising for UK deregulation following Brexit (including politically), this paper does not advocate the Panglossian financial free zone or policy geared around excessive deregulation, espoused by others, particularly given the related risks of a race to the bottom. ${ }^{140}$ The UK will have

\footnotetext{
134 Cleary (2018).

135 See e.g. International Organisation of Securities Commissions (2009). Indeed, national regulatory regimes are increasingly moulded by international standards, although they do vary in terms of levels of granularity. See Ferran (2018). On the other hand, the EU's uncompromising approach with respect to the equivalence of the requirements relating to Swiss stock exchanges looks less encouraging, see 'EUBased Traders Caught in Swiss “Equivalence” Spat', Financial Times, 30 June 2019; Moloney (2018a).

136 Coffee (2012).

137 Moloney (2010).

138 Jopson (2018); Moloney (2017c), pp 154-155; Coffee (2017), pp 14-15.

139 A good illustration in the securities and markets sector is the UK's 'premium' listing option for companies joining the UK's stock markets, which raises the bar beyond that required by EU law, see further e.g. Clifford Chance (2014); Gullifer and Payne (2015), chapter 10. With respect to the banking sector, see also e.g. 'Bank of England Needs Freedom to Set Tough Rules, Says Mark Carney', Financial Times, 17 July 2018, https://www.ft.com/content/95343036-899d-11e8-b18d-0181731a0340 (accessed 6 Aug 2018).

140 See e.g. Reynolds (2016); 'Brexit Is a Golden Chance to Throw Some EU Regulations on a Bonfire', The Telegraph, 28 March 2017.
} 
more capacity to shape regulation globally via the International Standard Setting Bodies if the UK and the EU remain closely connected. Certainly, both the UK and the EU have a common interest in a well-functioning international financial system that they can contribute to and seek to influence. ${ }^{141}$ This also appears to be envisaged in the Draft Political Declaration for the future UK/EU framework that refers to their close cooperation with respect to regulatory and supervisory matters. ${ }^{142}$

Rather, the paper advocates a UK domestic policy framed around strands of regulatory competition. This would occur in those carefully targeted areas where the UK can marshal its core strengths and develop credible alternatives or ambitious new approaches where an existing policy of EU harmonisation (such as the AIFMD) has underperformed and created difficulties for market sectors. ${ }^{143}$ Drawing on the paper's observations, the proposed Brexit-related regulatory autonomy in relation to the AIFMD would apply to the UK's permitted pre-marketing practices in relation to professional investors, and its wider policy on third country access arrangements. Further, for both the AIFMD and UCITS, such a position could also involve the UK taking an accommodating view on its delegation mechanisms. More broadly, the UK could also seek to be a first mover and embrace the opportunity to do some things differently over the longer-term, particularly when new challenges emerge for the CIS sector. ${ }^{144}$ Certainly, given the impact fintech could have on the CIS sector, the UK adopting a innovative approach to the domestic CIS industry could help strengthen its competitive position. This would be not so much in relation to trying to directly compete with the EU but with respect to the world stage. ${ }^{145}$

\section{Conclusion}

One of the key issues arising from the UK's divorce from the EU is the extent to which the UK should continue to shadow EU law. ${ }^{146}$ These tensions have been elucidated upon in this paper using the case study of the CIS sector: on the one hand ensuring cross-border activity is not disrupted in the short to medium term via a preservation of current arrangements; versus the scope for change to offer some competitive advantage to the UK; whilst juggling the related risk this generates with respect to EU equivalence decisions.

With respect to CIS regulation, the paper argues that it would be prudent for the UK to retain sufficient alignment with EU law to provide sufficient certainty for businesses in the aftermath of Brexit. UK UCITS will either have to re-domicile to the EU or be classified as alternative funds. Hence, the AIFMD third

\footnotetext{
141 See e.g. Reynolds (2017); Ferran (2017).

142 Draft Political Declaration setting out the framework for the future relationship between the European Union and the United Kingdom (2018), https://www.gov.uk/government/publications/withdrawal -agreement-and-political-declaration (accessed 23 Aug 2019), section IV.

143 Ferran (2017).

144 House of Lords European Union Select Committee (2016).

145 Moloney (2017c).

146 Armstrong (2018).
} 
country rules take on even greater significance. Under the AIFMD, UK managers will need to comply with the AIFMD third country private placement regime, which is Member State specific. Further, retaining alignment with EU provisions will also be key for the UK to be regarded as sufficiently equivalent to be granted the AIFMD third country passport (if this is activated). The delegation route may provide some assistance to the UK CIS sector but this is by no means a universal cure.

The paper then considers the current EU initiatives in the CIS sector to examine where UK regulation could start to deviate and apply a more accommodating framework, provided it remains in accordance with international standards. This could also be offered in an optional form for UK firms in order to offer maximum flexibility for businesses. Of itself, this shows that a strategy of limited regulatory divergence could start to materialise in particular areas, but that this may vary within industries as well as between them. Certainly, when this is considered at the level of the global arena, there could be further such spaces for the UK to be pro-active and drive future regulatory change. As evidenced within the example of CIS sector, in rapidly changing international environments, where fintech is emerging as a global phenomenon posing new opportunities and challenges, the UK should advance itself as a nation taking an international perspective to regulation, particularly where such issues have a global reach.

Acknowledgements I am grateful to Professor Niamh Moloney and the EBOR referee for their valuable comments and to Michael Sholem for discussions on this topic. The usual disclaimers apply.

Open Access This article is licensed under a Creative Commons Attribution 4.0 International License, which permits use, sharing, adaptation, distribution and reproduction in any medium or format, as long as you give appropriate credit to the original author(s) and the source, provide a link to the Creative Commons licence, and indicate if changes were made. The images or other third party material in this article are included in the article's Creative Commons licence, unless indicated otherwise in a credit line to the material. If material is not included in the article's Creative Commons licence and your intended use is not permitted by statutory regulation or exceeds the permitted use, you will need to obtain permission directly from the copyright holder. To view a copy of this licence, visit http://creativecommons.org/licen ses/by/4.0/.

\section{References}

AIMA (2016) ESMA guidance on AIFMD passport to non-EU countries-go slow persists. https://www. aima.org/journal/aima-journal-edition-108/article/esma-guidance-published-on-application-of-theaifmd-passport-to-non-eu-countries-go-slow-persists.html. Accessed 23 Sept 2019

AIMA (2018) Brexit and alternative asset managers: managing the impact. https://www.aima.org/resou rce/brexit-and-alternative-asset-managers-managing-the-impact.html. Accessed 23 Sept 2019

Armour J (2017) Brexit and financial services. Oxf Rev Econ Policy 33:S54-S69

Armstrong K (2018) Regulatory alignment and divergence after Brexit. J Eur Public Policy 25:1099-1117

Ashurt (2016) Brexit: potential impact on the asset management industry. https://www.ashurst.com/en/ news-and-insights/insights/brexit-potential-impact-on-the-asset-management-industry/. Accessed 23 Sept 2019

Ashurt (2018) Amazing ideas for marketing disasters (AIFMD) marketing AIFs might get more nonsensical. https://www.ashurst.com/en/news-and-insights/legal-updates/amazing-ideas-for-marketingdisasters_aifmd-marketing-aifs-might-get-more-nonsensical/. Accessed 23 Sept 2019 
Association of the Luxembourg Fund Industry (2012) How UCITS funds protect investors

Binham C (2018) FCA's Bailey slams EU's post-Brexit plans for asset managers. Financial Times, 26 April 2018. https://www.ft.com/content/763321fe-4971-11e8-8ae9-4b5ddcca99b3. Accessed 5 June 2018

Blitz J (2018) Brexit transition is agreed-but at a price. Financial Times, 19 March 2018. https://www. ft.com/content/d1efaf62-2b71-11e8-9b4b-bc4b9f08f381. Accessed 7 Aug 2018

Buckley J, Howarth D (2010) Internal market: gesture politics? Explaining the EU's response to the financial crisis. J Common Mark Stud 48:119-261

Callaghan H, Höpner M (2005) European integration and the clash of capitalisms: political cleavages over takeover liberalization. Comp Eur Polit 3:307-332

Carey O (2017) A guide to funds and private equity in Jersey. https://www.careyolsen.com/sites/defau 1t/files/CO_JSY_IF_A\%20guide\%20to\%20funds\%20and\%20private\%20equity\%20in\%20Jer sey_3.17\%20v5.pdf. Accessed 23 Sept 2019

Cleary G (2018) EU Commission proposals to harmonise the cross-border distribution of funds and define 'pre-marketing'. https://www.clearygottlieb.com/-/media/files/alert-memos-2018/eu-propo sals-to-harmonize-cross-border-fund-distribution-and-regulate-pre-marketing.pdf. Accessed 23 Sept 2019

Clifford Chance (2014) Initial public offers: a guide to the UK listing regime. https://financialmarketstool kit.cliffordchance.com/content/micro-facm/en/financial-markets-resources/resources-by-type/guide s/a-guide-to-the-uk-listing-regime/_jcr_content/parsys/download/file.res. Accessed 23 Sept 2019

Clifford Chance (2016) Brexit: assessing the impact on asset managers. https://www.cliffordchance.com/ briefings/2016/07/brexit_assessingtheimpactonassetmanagers.html. Accessed 23 Sept 2019

Clift B (2009) The second time as farce? The EU takeover directive, the clash of capitalisms and the hamstrung harmonization of European (and French) corporate governance. J Common Mark Stud 47:55-79

Coffee J (2012) The political economy of Dodd-Frank: why financial reform tends to be frustrated and systemic risk perpetuated. Cornell Law Rev 97:1019-1082

Coffee J (2017) How should the EU respond to Brexit and Trump? The lessons of trade wars. Columbia Law School Working Paper. https://scholarship.law.columbia.edu/cgi/viewcontent.cgi?artic le=3050\&context=faculty_scholarship. Accessed 23 Sept 2019

Davies A, MacAskill A (2017) France in talks with up to 50 asset managers on post-Brexit plans. Reuters, 7 June 2017. https://uk.reuters.com/article/us-britain-eu-asset-managers-idUKKBN18Y1PU. Accessed 3 Aug 2018

Davis P (2016) The law and Brexit: issue 8. https://www.davispolk.com/files/2016-10-24-lex-et-brexi t-law-brexit-issue-8.pdf. Accessed 23 Sept 2019

Debevoise and Plimpton (2018) European Commission proposes harmonised pre-marketing rules for funds. https://www.debevoise.com/insights/publications/2018/03/european-commission-proposesharmonised. Accessed 23 Sept 2019

Dohle M (2017) Battle for Brexit business: Frankfurt's aim to attract firms leaving the UK. November 2017. http://www.investmenteurope.net/regions/germany/battle-brexit-business-frankfurts-aimattract-firms-leaving-uk/. Accessed 16 Apr 2018

ECOFIN (2019a) Presidency compromise proposal (ESAs framework excluding AML). 5834/19

ECOFIN (2019b) Compromise Proposal regard to cross-border distribution of collective investment funds. 6615/19

EFAMA (2017) Asset management in Europe. https://www.efama.org/Publications/Statistics/Asset \%20Management\%20Report/Asset\%20Management\%20Report\%202017.pdf. Accessed 23 Sept 2019

Ernst and Young (2017) The implications of Brexit on UK asset managers

ESMA (2013) Guidelines on the model MoU concerning consultation, cooperation and the exchange of information related to the supervision of AIFMD entities. 2013/998

ESMA (2016) Advice on the application of the AIFMD passport to non-EU AIFMs and AIFs. ESMA 2015/1236. https://www.esma.europa.eu/sites/default/files/library/2015/11/2015-1236_advice_to_ ep-council-com_on_aifmd_passport.pdf. Accessed 21 Jan 2020

ESMA (2017) Opinion to support supervisory convergence in the context of the UK's withdrawal from the EU. https://www.esma.europa.eu/sites/default/files/library/esma70-154-270_opinion_to_suppo rt_supervisory_convergence_in_the_area_of_secondary_markets_in_the_context_of_the_unite d_kingdom_withdrawing_from_the_european_union.pdf. Accessed 21 Jan 2020 
Europe Economics (2016) FCA's market study and Brexit: next challenges for the UK asset management industry. http://www.europe-economics.com/publications/asset_management.pdf. Accessed 21 Jan 2020

Europe Economics (2017) Evaluation of the Alternative Investment Fund Managers Directive

European Commission (2015) Action plan on building a Capital Markets Union. COM(2015) 468 final

European Commission (2017a) Commission Communication on the mid-term review of the Capital Markets Union action plan. COM(2017) 292 final

European Commission (2017b) EU equivalence decisions in financial services policy: an assessment. $\operatorname{SWD}(2017) 102$ final

European Commission (2017c) ESAs' review: proposal. COM(2017) 536 final

European Commission (2018a) Notice to stakeholders: withdrawal of the UK and EU rules in the field of asset management. February 2018. https://ec.europa.eu/info/sites/info/files/180208-notice-withd rawal-uk-asset-management_en.pdf. Accessed 21 Jan 2020

European Commission (2018b) Impact assessment. SWD(2018) 54 final

European Commission (2018c) Proposal for a Directive amending Directive 2009/65/EC and Directive 2011/61/EU with regard to cross-border distribution of collective investment funds. COM(2018) 92 final

European Commission (2018d) Proposal for a Regulation on facilitating cross-border distribution of collective investment funds. COM(2018) 110 final

European Council (2016) A new settlement for the United Kingdom within the EU. OJ 2016, C 69 I/1

European Parliament (2016) Brexit: the United-Kingdom and EU financial services. https://www.europ arl.europa.eu/RegData/etudes/BRIE/2016/587384/IPOL_BRI\%282016\%29587384_EN.pdf. Accessed 21 Jan 2020

European Parliament (2018a) Draft report on cross-border distribution of CIFs. 2018/0041(COD)

European Parliament (2018b) MEPs votes on cross-border CIFs. Press release, December 2018

FCA (2017) Asset management market study: final report. June 2017. https://www.fca.org.uk/publicatio n/market-studies/ms15-2-3.pdf. Accessed 21 Jan 2020

FCA (2018a) Asset management market study: policy statement. PS18/8. https://www.fca.org.uk/publi cation/policy/ps18-08.pdf. Accessed 21 Jan 2020

FCA (2018b) Consultation on further remedies-asset management market study. CP18/9. https://www. fca.org.uk/publication/consultation/cp18-09.pdf. Accessed 21 Jan 2020

FCA (2019) FCA agrees MoUs with ESMA and EU regulators to allow cooperation and exchange of information. https://www.fca.org.uk/news/press-releases/fca-agrees-mous-esma-and-eu-regulators -allow-cooperation-and-exchange-information. Accessed 23 Sept 2019

Ferran E (2004) Building an EU securities market. Cambridge University Press, Cambridge

Ferran E (2011) After the crisis: the regulation of hedge funds and private equity in the EU. EBOR 12:379-414

Ferran E (2012) Crisis-driven regulatory reform: where in the world is the EU going? In: Ferran E et al (eds) The regulatory aftermath of the global financial crisis. Cambridge University Press, Cambridge, pp 1-110

Ferran E (2017) The UK as a third country actor in EU financial services regulation. J Financ Regul Compliance 3:40-65

Ferran E (2018) Regulatory parity in post-Brexit UK-EU financial regulation. In: Alexander K, Barnard C, Ferran E, Lang A, Moloney N (eds) Brexit and financial services: law and policy. Hart Publishing, Oxford, pp 1-38

Ferran E, Ho LC (2014) Principles of corporate finance law, 2nd edn. Oxford University Press, Oxford

Financial Stability Board (2017) Policy recommendations to address structural vulnerabilities from asset management activities. https://www.fsb.org/2017/01/policy-recommendations-to-address-struc tural-vulnerabilities-from-asset-management-activities/. Accessed 23 Sept 2019

FSA (2009) The Turner review: a regulatory response to the global banking crisis. March 2009. https ://webarchive.nationalarchives.gov.uk/20091203184338/http://www.fsa.gov.uk/pubs/other/turne r_review.pdf. Accessed 20 Jan 2020

Geithner T (2010) Letter dated 1 March 2010 to Michel Barnier, the Commissioner for the Internal Market and Services. As published in the Financial Times, 11 March 2010

Glen J (2018) Economic Secretary to HM Treasury, Response to House of Commons European Scrutiny Committee report on cross-border distribution of collective investment funds proposals. July 2018. http://europeanmemoranda.cabinetoffice.gov.uk/files/2018/07/Scan_\%2811\%291.pdf. Accessed 23 Sept 2019 
Gullifer L, Payne J (2015) Corporate finance law: principles and policy, 2nd edn. Hart Publishing, Oxford Hall P, Soskice D (2001) Varieties of capitalism: the institutional foundations of comparative advantage. Oxford University Press, Oxford

HM Government (2018) The future relationship between the United Kingdom and the European Union. July 2018. https://www.gov.uk/government/publications/the-future-relationship-between-the-unite d-kingdom-and-the-european-union. Accessed 23 Sept 2019

House of Commons European Scrutiny Committee (2018) Twenty-sixth report of session 2017-2019. https://publications.parliament.uk/pa/cm201719/cmselect/cmeuleg/301-xxv/301-xxv.pdf. Accessed 23 Sept 2019

House of Lords European Union Committee (2016) Brexit: financial services report. https://publicatio ns.parliament.uk/pa/ld201617/ldselect/ldeucom/81/81.pdf. Accessed 23 Sept 2019

House of Lords European Union Committee (2018) Brexit: the future of financial regulation and supervision. HL Paper No 66. https://publications.parliament.uk/pa/ld201719/1dselect/ldeucom/66/66.pdf. Accessed 23 Sept 2019

House of Lords European Union Select Committee (2015) The post-crisis EU financial regulatory framework: do the pieces fit? 5th Report of session 2014-2015. https://publications.parliament.uk/pa/ ld201415/ldselect/ldeucom/103/103.pdf. Accessed 23 Sept 2019

Howarth D, Quaglia L (2014) Hedge funds. In: Mügge D (ed) Europe and the governance of global finance. Oxford University Press, Oxford, pp 113-126

Howarth D, Quaglia L (2017) Brexit and the single European financial market. J Common Mark Stud 55:149-164

Howarth D, Quaglia L (2018) Brexit and the battle for financial services. J Eur Public Policy 25:1118-1136

International Monetary Fund (2016) United Kingdom, financial system stability assessment (FSAP). https://www.imf.org/external/pubs/ft/scr/2016/cr16167.pdf. Accessed 23 Sept 2019

International Organisation of Securities Commissions (2009) Hedge funds oversight: final report. https:// www.iosco.org/library/pubdocs/pdf/IOSCOPD293.pdf. Accessed 23 Sept 2019

International Organisation of Securities Commissions (2018) Recommendations for liquidity risk management for collective investment schemes: final report. FR01/2018. https://www.iosco.org/library/ pubdocs/pdf/IOSCOPD590.pdf. Accessed 23 Sept 2019

Investment and Pensions Europe (2018) Asset managers warn on delegation oversight plans Amid TALK of relief. May 2018. https://www.ipe.com/asset-managers-warn-on-delegation-oversight-plans -amid-talk-of-relief/10024477.article. Accessed 27 Jan 2020

Jopson B (2018) US Congress rolls back parts of post-crisis bank rules. Financial Times, 22 May 2018. https://www.ft.com/content/649e6d66-5deb-11e8-ad91-e01af256df68. Accessed 20 June 2018

KPMG (2017) Move to centralised regulation of EU funds and delegation arrangements. https://home. kpmg/xx/en/home/insights/2017/09/moves-to-centralised-regulation-of-eu-funds-and-delegation -arrangements-fs.html. Accessed 23 Sept 2019

Lannoo K (2017) Brexit and the asset management industry. ECMI Policy Brief. https://www.ceps.eu/ wp-content/uploads/2017/02/ECMI\%20PB23\%20KL\%20Brexit\%20and\%20the\%20asset\%20man agement\%20industry.pdf. Accessed 23 Sept 2019

Latham M (2018) French regulator cranks up Brexit pressure on UK asset managers. March 2018. http:// www.funds-europe.com/news/french-regulator-cranks-up-brexit-pressure-on-uk-asset-managers. Accessed 16 Apr 2018

Lehmann M, Zetzsche D (2018) How does it feel to be a third country? The consequences of Brexit for financial market law. CIGI \& BIICL, Brexit: the international legal implications: Paper No 14

Maijoor S (2018) Opening remarks: CMU, Brexit and ESA review-what's next? https://www.esma. europa.eu/press-news/esma-news/steven-maijoor-cmu-brexit-and-esa-review-\%E2\%80\%93what $\%$ E2\%80\%99s-next. Accessed 23 Sept 2019

Moloney N (2010) EU financial market regulation after the global financial crisis: 'more Europe' or more risks? CMLR 47:1317-1383

Moloney N (2014) EU securities and financial markets regulation, 3rd edn. Oxford University Press, Oxford

Moloney N (2016) International financial governance, the EU, and Brexit: the 'agencification' of EU financial governance and the implications. EBOR 17:451-480

Moloney N (2017a) Brexit, the EU and its investment banker: rethinking 'equivalence' for the EU capital market. LSE Law, Society and Economy Working Papers No 5 
Moloney N (2017b) Brexit and EU financial governance: business as usual or institutional change? ELJ 42:112-128

Moloney N (2017c) Financial services governance. In: Dougan M (ed) The UK after Brexit: legal and policy challenges. Intersentia, Cambridge, pp 135-158

Moloney N (2018a) Brexit and financial services: (yet) another re-ordering of institutional governance for the EU financial system? CMLR 55:175-201

Moloney N (2018b) EU financial governance after Brexit: the rise of technocracy and the absorption of the UK's withdrawal. In: Alexander K, Barnard C, Ferran E, Lang A, Moloney N (eds) Brexit and financial services: law and policy. Hart Publishing, Oxford, pp 61-113

Münchau W (2018) Germany is frustrating Emmanuel Macron's grand ambitions. Financial Times, 13 April 2018

Politi J (2010) Geithner urges EU fund rules rethink. Financial Times, 6 April 2010

PricewaterhouseCoopers (2018) Impact of loss of mutual market access in financial services across the EU27 and UK. February 2018. https://www.pwc.co.uk/financial-services/assets/pdf/impact-ofbrexit-on-fs-in-europe.pdf. Accessed 23 Sept 2019

Quaglia L (2010) Completing the single market in financial services: the politics of competing advocacy coalitions. J Eur Public Policy 17:1007-1023

Quaglia L (2011) The 'old' and 'new' political economy of hedge fund regulation in the European Union. West Eur Polit 34:665-682

Quaglia L (2015) The politics of 'third country equivalence' in post-crisis financial services regulation in the European Union. West Eur Polit 38:167-184

Reynolds B (2016) A blueprint for Brexit: the future of global financial services and markets in the UK. Politeia, London

Reynolds B (2017) A template for enhanced equivalence: creating a lasting relationship in financial services between the EU and the UK. Politeia, London

Ringe WG (2017) The irrelevance of Brexit for the European financial market. Oxford Legal Research Paper. https://ecgi.global/sites/default/files/The\%20Irrelevance\%20of\%20Brexit\%20for\%20the \%20European\%20Financial\%20Market.pdf. Accessed 23 Sept 2019

Ringe W-G, Ruof C (2018) A regulatory sandbox for robo advice. European Banking Institute Working Paper Series No 26

Schaub A (2004) Director-General, DG Internal Market of the European Commission: testimony before the US House of Representatives. May 2004. https://www.iasplus.com/en/binary/resource/05130 4as.pdf. Accessed 23 Sept 2019

Schnittker Möllman Partners (2018) EU Commission proposal: narrowing the 'pre-marketing' concept. https://www.smp.law/EN/Briefing/Fund_Briefing_EU_Commission_proposal_copy.php. Accessed 23 Sept 2019

The Investment Association (2017) Asset management in the UK: annual survey 2016-2017. https:// www.theia.org/sites/default/files/2019-05/20170914-ams2017.pdf. Accessed 23 Sept 2019

The Investment Association (2018a) Asset management in the UK: annual survey 2017-2018. https:// www.theia.org/sites/default/files/2019-04/20180913-fullsummary.pdf. Accessed 23 Sept 2019

The Investment Association (2018b) Beyond Brexit: a new partnership with the EU for the asset management industry. https://www.theia.org/sites/default/files/2019-04/20180608-beyondbrexit.pdf. Accessed 23 Sept 2019

Walker O (2018a) Spooked fund managers look at rivals to London. Financial Times, 17 Feb 2018

Walker O (2018b) US raises pressure over EU plan for changes to fund rules. Financial Times, 5 February 2018. https://www.ft.com/content/6dc2406a-0815-11e8-9650-9c0ad2d7c5b5. Accessed 5 June 2018

Walker O (2018c) EU steps back from tough new fund management rules. Financial Times, 27 April 2018. https://www.ft.com/content/7607117e-49ec-11e8-8ae9-4b5ddcca99b3. Accessed 5 June 2018

Wei T-B (2007) The equivalence approach to securities regulation. Northwest J Int Law Bus 27:255-299

Zimmermann H (2009) Varieties of global financial governance? In: Helleiner E, Pagliari S, Zimmermann $\mathrm{H}$ (eds) Global finance in crisis: the politics of international regulatory change. Routledge, London, pp 121-136

Publisher's Note Springer Nature remains neutral with regard to jurisdictional claims in published maps and institutional affiliations. 